\title{
PREVALENCE AND ECONOMIC IMPACT OF CYSTICERCUS BOVIS IN SLAUGHTERED CATTLE IN MENOFIA PROVINCE, EGYPT
}

\author{
AHMED O. ELKHTAM* ${ }^{*}$, IBRAHIM A. MOSTAFA², REYAD R. SHAWISH ${ }^{3}$ \\ ${ }^{* 1}$ Department of Parasitology, Faculty of Veterinary Medicine., University of Sadat City, Sadat City \\ 32511, Menofia, Egypt, \\ 2Department of Husbandry and Animal Wealth Development, Faculty of Veterinary Medicine, \\ University of Sadat City, Sadat City 32511, Menofia, Egypt \\ ${ }^{3}$ Department of Food Hygiene and Control, Faculty of Veterinary Medicine, University of Sadat City, \\ Sadat City 32511, Menofia, Egypt \\ *Corresponding author: Ahmed Elkhtam, Ph. D. \\ Department of Parasitology, Faculty of Veterinary Medicine, University of Sadat City, Sadat City \\ 32511, Menofia, Egypt· Phone: 2-048-2603215, E-mail: elkhtama@yahoo.com
}

\begin{abstract}
Bovine cysticercosis considered to be a dangerous problem for both public health and the livestock economy. The present study aimed to determine the cysticercus bovis prevalence and their economic losses in slaughtered cattle in Menofia governorate. Visual meat inspection of 2640 cattle carcasses at different abattoirs of Menofia governorate was carried out allover one year extended from January 2015 to December 2015. The results revealed that, the prevalence of cysticercus bovis in slaughtered cattle was $6.09 \%$ and the affected organs were head (masseter and tongue), heart and whole carcass with infection rates of $3.63 \%, 2.42 \%$ and $0.04 \%$ respectively. Moreover, the morphological description and measurements of recovered cysticercus bovis were recorded. It was observed that, the cysticercosis cause sever economic losses, as the estimated annual financial losses of cysticercosis in slaughtered cattle was 87032 Egyptian Pound (EGP).
\end{abstract}

Key words: Bovine cysticercosis, financial losses, slaughtered cattle.

\section{INTRODUCTION}

Cysticercosis in cattle is a food borne disease caused by Taenia saginata with humans as the final host and cattle as the intermediate host. Infection of human by Taenia saginata occurs through ingestion of raw or undercooked meat containing cysticercus bovis. While, infection of cattle with cysticercus bovis occurs through ingestion of Taenia saginata eggs ( Dupuy et al., 2014). Cysticercus bovis is the metacestode of beef tapeworm (Taenia saginata). Adult Taenia saginata measured 30 meter long and found in human small intestine (Gracey et al.,1999) which pass daily millions of eggs that resist adverse environmental conditions (Urquhart et al.1988), (Rommel et al.2000). Lesions caused by bovine cysticercosis may be confused with
Sarcocystis (Ogunremi et al.2004). Bovine cysticercosis is world wide distributed disease and considered to be a dangerous problem for the livestock economy and public health, common in different countries of Africa, reaching a level of $33 \%$ in Kenya, $80 \%$ in Ethiopia and $8 \%$ in Sudan (Urquhart et al., 2007). Annual losses in Africa due to cysticercus bovis were $\$ 1.8$ billion (Harrison 1996). the prevalence of cysticercus bovis ranges between 0.01 and $6.8 \%$ in various European countries (SCVPH 2000) according to meat inspection, the occurrence of Cysticercus bovis in cattle slaughtered in Croatian abattoir by physical inspection allover 5 years and recorded that their infection rate was $0.11 \%$ (Zdolec et al., 2012), 
but the expected prevalence is to be between three and ten times higher (Onyango-Abuge et al.1996; Dorny et al.2000). Economic losses In the meat industry due to cysticercosis are closely Related to the infection degree. In generalized cysticercosis; the carcass must be condemned totally.

While, condemnation of the infected parts in localized cysticercosis must be applied. In addition to, the carcass should be stored in at a temperature not exceeding $-7^{\circ} \mathrm{C}$ for period of 3 weeks for keeping the parasites inactivate (Gracey et al. 1999).

\section{MATERIALS AND METHODS}

\section{Study area}

The study was carried out allover one year extended from January 2015 to December 2015 at different abattoirs of Menofia governorate (Ashmoun, El Shouhada and Shebein El Kom abattoirs) to determine the prevalence of cysticercus bovis and their economic impact in slaughtered cattle.

\section{Animals and Cysticercus bovis collection}

The present study was conducted on 2640

cattle of different sexes and ages.

The whole carcasses of 2640 adult slaughtered cattle were physically inspected for presence of cysticercus bovis. The recovered Cysts from each infected carcass were collected in separate container, washed in normal saline, examined macroscopically for viability to cattle were determine viable or dead cyst. The live cyst cercus bovis were slightly pressed between 2 glass slides and fixed in 10\% formalin for microscopical examination. The samples were stained with Mayer's carmalum stain and mounted (MAFF 1986). These cysts were identified according (Soulsby 1986 ; Urquhart et al.1988)

Estimation of economic losses
The economic loss due to organ condemnation was calculated according to the following equation:

$\mathbf{E L}=\mathbf{N} \times \mathbf{P} \times \mathbf{W}$ Where, EL: Economic losses; N: Number of condemned organs; P: Average organ price $(\mathrm{EGP} / \mathrm{kg})$; $\mathrm{W}$ : Average organ weight $(\mathrm{kg})$

\section{RESULTS AND DISCUSSION}

\section{Prevalence of cysticercus bovis}

The results in table (1) showed the prevalence of Cysticercus bovis of slaughtered cattle at different abattoirs of Menofia governorate. Meat inspection of slaughtered cattle indicated that 161 out of 2640 (6.09\%) had Cysticercus bovis. Concerning the locality, 80 out of 1320 examined cattle were infected with Cysticercus bovis at Ashmoun abattoir. While, 43 out of 720 and 38 out of 600 inspected carcasses were infected with Cysticercus bovis at El Shouhada and Shebein El Kom abattoirs with an infection rate of $5.97 \%$ and $6.33 \%$ respectively. Regarding to the infected organs, 96 heads out of 2640 examined cattle were infected with Cysticercus bovis with an infection rate $3.63 \%$ ( 48 Ashmoun, 23 El Shouhada and 25 Shebein El Kom). In addition to, 64 hearts out of 2640 cysticercosis infected with infection rate of 2.42\% (32 Ashmoun, 20 El Shouhada and 12 Shebein El Kom). Total condemnation were carried out in one carcass with a rate of $0.04 \%$ ( 1 out of 2640 ). The total condemned carcass was reported in Shebein El Kom abattoir with an infection rate of $0.16 \%$ of the examined cattle.

The seasonal prevalence of Cysticercus bovis was recorded that the highest infection rates were $15.38 \%$ in spring season followed by $13.04 \%$ in autumn season. While the lowest infection with cysticercosis was $4.85 \%$ in winter season Figure 
Table (1) Prevalence of Cysticercus bovis in different organs and localities.

\begin{tabular}{|c|c|c|c|c|c|c|}
\hline \multirow{2}{*}{ Locality } & \multicolumn{2}{|c|}{$\begin{array}{c}\text { Ashmoun } \\
\text { No. examined } \\
\text { Organs }\end{array}$} & \multicolumn{2}{|c|}{$\begin{array}{c}\text { El Shouhada } \\
\text { No. examined } \\
\text { (1320) }\end{array}$} & \multicolumn{2}{|c|}{$\begin{array}{c}\text { Shebein El Kom } \\
\text { No. examined } \\
\text { (600) }\end{array}$} \\
\cline { 2 - 7 } & $\begin{array}{c}\text { No. } \\
\text { infected }\end{array}$ & $\begin{array}{c}\text { \% of } \\
\text { infection }\end{array}$ & No. infected & $\begin{array}{c}\text { \% of } \\
\text { infection }\end{array}$ & $\begin{array}{c}\text { No. } \\
\text { infected }\end{array}$ & $\begin{array}{c}\text { \% of } \\
\text { infection }\end{array}$ \\
\hline $\begin{array}{c}\text { Head } \\
\text { (masseter and tongue) }\end{array}$ & 48 & 3.63 & 23 & 3.19 & 25 & 4.17 \\
\hline Heart & 32 & 2.42 & 20 & 2.77 & 12 & 2 \\
\hline Whole carcass & 0 & 0 & 0 & 0 & 1 & 0.16 \\
\hline Total & 80 & 6.06 & 43 & 5.97 & 38 & 6.33 \\
\hline
\end{tabular}

\section{Seasonal prevalence of Cysticercus bovis}

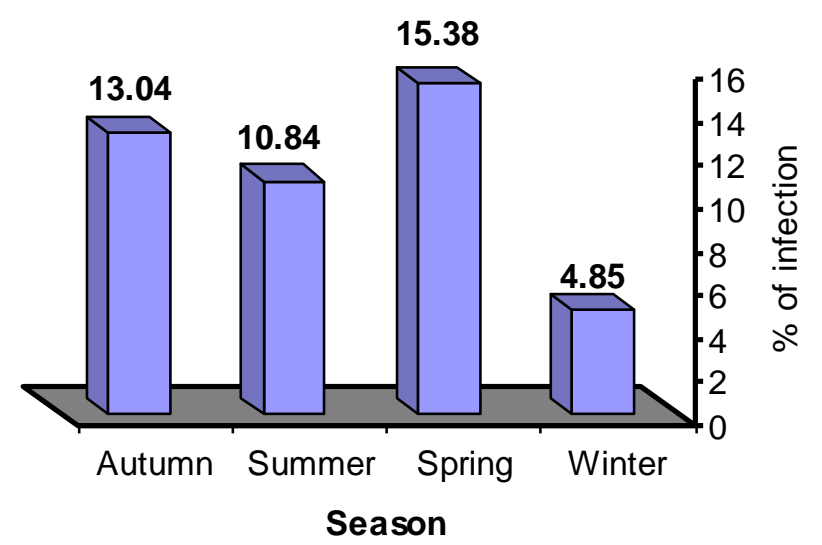

\section{$\square$ Cysticercus bovis}

Figure ( 1) Seasonal prevalence of Cysticercus bovis

Morphological description and measurements of cysticercus bovis

Morphological description of the collected cysticercus bovis was recorded. Macroscopical and microscopical examination of The collected cysticercus bovis was reported. A Viable cysticercus bovis was white fluid filled cyst containing protoscolex, these cyst were measured $3.50 \times 5.50-6.00 \times 10.50 \quad(4.75 \times 8.00)$ $\mathrm{mm}$. while, the protoscolices were $1.50 \times 1.70$ $1.60 \times 2.00(1.55 \times 1.85) \mathrm{mm}$. in addition to, each Scolex contained 4 suckers. Each sucker were measured $\quad 0.20 \times 0.25-0.24 \times 0.29 \quad(0.22 \times 0.27)$ $\mathrm{mm}$. the dead cysticercus bovis was calcified with caseated content. these measurements were reported in Table (2) and their morphology were showed in Figure (2).

$90 \%$ of recovered cysticercus bovis were dead cyst while $10 \%$ of recovered cyst were viable cysts. all recovered viable cysticercus bovis were recovered from heads of examined carcasses.

Economic losses of cysticercus bovis in slaughtered cattle

The annual total economic losses from condemned parts that infected with cysticercus bovis in slaughtered cattle were 87032 EGP. Moreover, the economic losses from condemned heads were 63960 EGP while, the losses were 7072 EGP from condemned hearts annually. Furthermore, the economic losses from condemned one whole carcass was 16000 EGP. So the condemned heads represented $74 \%$ from total losses, then whole carcass $18 \%$, followed by hearts $8 \%$ respectively. The highest economic losses were recorded from condemnation of the heads Table (3) and Figure (3) 
Table (2) Measurements of the recovered cysticercus bovis in millimeters.

\begin{tabular}{|c|c|c|c|}
\hline & $\begin{array}{c}\text { Total size } \\
(\mathrm{mm})\end{array}$ & $\begin{array}{c}\text { Scolex } \\
(\mathrm{mm})\end{array}$ & $\begin{array}{c}\text { Sucker } \\
(\mathrm{mm})\end{array}$ \\
\hline Cysticercus bovis & $3.50 \times 5.50-6.00 \times 10.50$ & $1.50 \times 1.70-$ & $0.20 \times 0.25-0.24 \times 0.29$ \\
& $(4.75 \times 8.00)$ & $1.60 \times 2.00$ & $(0.22 \times 0.27)$ \\
& & $(1.55 \times 1.85)$ & \\
\hline
\end{tabular}

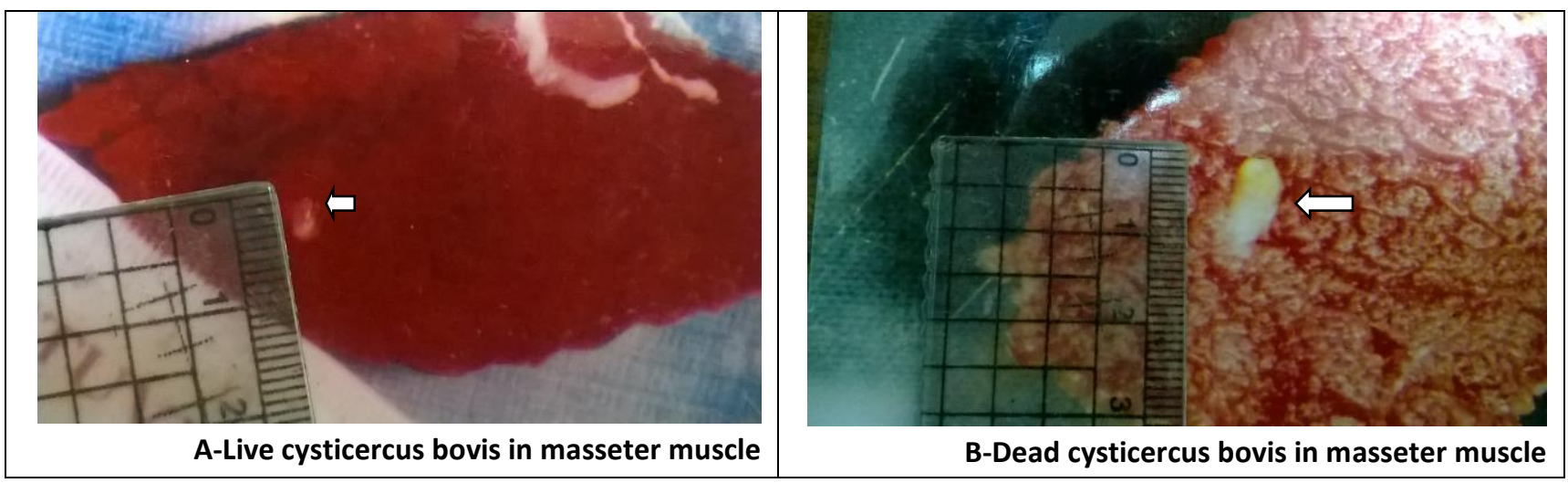

Figure (2) live and dead cysticercus bovis

Table (3): Estimated annual economic losses of cysticercosis in slaughtered cattle/ Egyptian Pound (EGP)

\begin{tabular}{|c|c|c|c|c|c|}
\hline $\begin{array}{c}\text { Condemned } \\
\text { part }\end{array}$ & $\begin{array}{c}\text { No. of } \\
\text { infected } \\
\text { animal }\end{array}$ & Weight $(\mathrm{kg})$ & $\begin{array}{c}\text { Total } \\
\text { condemned } \\
(\mathrm{kg})\end{array}$ & $\begin{array}{c}\text { Price } \\
/ \mathrm{kg} \\
(\mathrm{EGP})\end{array}$ & $\begin{array}{c}\text { Total } \\
\text { loss } \\
(\mathrm{EGP})\end{array}$ \\
\hline Head & 96 & 11.10 & 1065.6 & 35 & 63960 \\
\hline Heart & 64 & 1.700 & 108.800 & 65 & 7072 \\
\hline Whole carcass & 1 & 320 & 320 & 50 & 16000 \\
\hline Total & 161 & 332.8 & 1494.4 & & 87032 \\
\hline
\end{tabular}

Total cost (EGP)

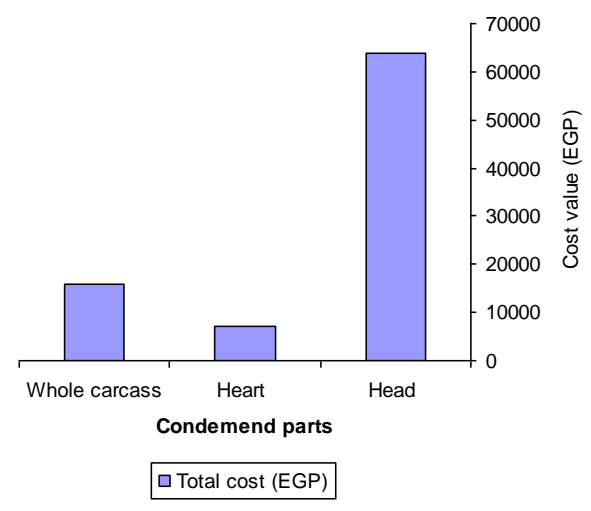

(A)
Total cost (EGP)

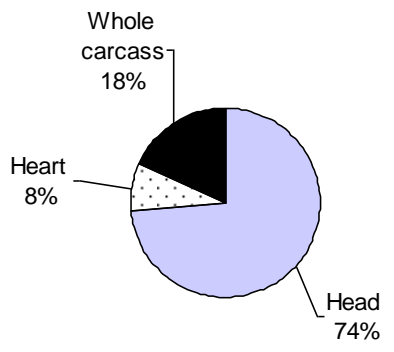

(B)

Special volume for the first International Conference of Genetic Engineering and Biotechnology, Sharm el Shiekh, Egypt. 26-29 April, 2016 
Figure (3): (A) cost value of affected parts with cysticercosis; (B) cost percentage ratio of affected parts with cysticercosis

The present study carried out on 2640 slaughtered cattle to determine the prevalence of cysticercus bovis and their economic losses in Menofia province. The study concluded that the infection rate of cysticercus bovis was $6.09 \%$. The highest infection rate of cysticercus bovis recorded during spring season (15.38\%) and the peak of infection observed during March (24.56\%). Higher infection rate of $54 \%$ was recorded by (Kambarage et al., 1995) in Tanzania. while, Lower infection rates were recorded by (Zivkovic et al., 1996) in Slovenia and (Zdolec et al., 2012) which were $0.78 \%$, and $0.11 \%$ respectively.

The Morphological description and measurements of cysticercus bovis was agreed with (Soulsby 1986).

The annual losses form condemned head, heart and whole carcass were 63960, 7072 and 16000 EGP respectively. These results agreed with (Assefa and Tesfay, 2013) who reported 1.5 million USD losses due to cysticercosis annually. 74\% from total losses due to cysticercosis were from the condemnation of infected heads, while, the condemned hearts represented $8 \%$. The highest economic losses were recorded from condemnation of the heads The variation in estimated losses may be attributed to variation in prevalence and localities of abattoirs.

\section{REFERENCES}

Assefa, A. and Tesfay, H. (2013). Major causes of organ condemnation and economic loss in cattle slaughtered at Adigrat municipal abattoir, northern, Ethiopia, Veterinary World, 6(10): 734-738.

Dorny, P., Vercammen, F., Brandt, J., Vansteenkiste, W., Berkvens, D. and Geerts, S. (2000). Sero-epidemiological study of Taenia saginata cysticercosis in Belgian cattle. Vet. Parasitol. 88:4349
Dupuy, C., Morlot, C., Gilot-Fromont, E., Mas, M., Grandmontagne, C., Gilli-Dunoyer, P., Gay, E. and Callait-Cardinal, M.P. (2014): Prevalence of Taenia saginata cysticercosis in French cattle in 2010. Vet Parasitol., 16;203(1-2):65-72.

Gracey, J., Collins, D.S. and Huey, R. (1999). Diseases caused by helminth and arthropod parasites. In: Meat hygiene, 10th edn. WB Saunders, UK, pp 635699.

Harrison, L.J.S. (1996). Epidemiology and control of Taenia saginata cysticercosis. Centre for Tropical Veterinary Medicine, University of Edinburgh, UK, R 5580.

Kambarage, D.M., Kimera, S.I., Kazwala, R.R. and Mafwere, B.M. (1995) . Disease conditions responsible for condemnation of carcasses and organs in short-horn Zebu cattle slaughtered in Tanzania. Preventive Veterinary Medicine 22, $249-255$.

MAFF (1986). Manual of Veterinary Parasitological Laboratory Techniques. Ministry of Agriculture, Fisheries and Food. Reference Book No. 418. Her Majesty`s Stationary Office, London, UK.

Ogunremi, O., MacDonald, G., Geerts, S. and Brandt, J, (2004), Diagnosis of Taenia saginata cysticercosis by immunohistochemical test on formalinfixed and paraffin-embedded bovine lesions. J. Vet. Diagn. Invest., 16:438441.

Onyango-Abuge, J.A., Hughes, G., Opicha, M., Nginyi, K.M., Rugutt, M.K., Wright, S.H. and Harrison, L.J. (1996). Diagnosis of Taenia saginata cysticercosis in Kenyan cattle by antibody and antigen ELISA. Vet Parasitol 61:221-230.

Rommel, M., Eckert, J., Kutzer, E., Körting, W. and Schnieder, T. (2000) .Taenia saginata -Zystizerkose. In: 
Veterinärmedizinische Parasitologie.

Barey Buchverlag, Berlin, Germany, pp 218-221.

SCVPH (Scientific Committee on Veterinary Measures Relating to Public Health) (2000) Opinion on the control of taeniosis/ cysticercosis in man and animals, adopted on $27-28$ September.(http://europa.eu.int/com $\mathrm{m} / \mathrm{food} / \mathrm{fs} / \mathrm{sc} / \mathrm{scv} /$ out36_en.pdf)

Soulsby, E.J.L. (1986). Heminths, Arthropods and protozoa of domesticated animals. 7th ed. Baillier, Tidal and Cassel, London.

Urquhart, G.M., Armor, J., Duncan, J.L., Dunn, A.M. and Jennings, F.W.(1988). Veterinary Parasitology. Longman Scientific and Technical, UK, pp 119120.

Urquhart, G.M., J. Armour, J.L. Duncan and F.W. Jennings, (2007). Veterinary Parasitology 2 ed. nd Long man group UK, 22: 123-126.
Zdolec, N., Vujevi, C., Dobrani, V., Juras, M., Grgurevi, N., Ardali, D. and Ngari, B. (2012). Prevalence of Cysticercus bovis in slaughtered cattle determined by traditional meat inspection in Croatian abattoir from 2005 to 2010. Helminthologia,49,4:229-232.

Zivkovic, J.,Velimirovic, D., Dzaja, P. and Grabarevic, Z. (1996). Prevalence of Cysticercus bovis $\mathrm{s}$ inermis measles with particular reference to histopathological changes in meat. Arch. Lebensmittelhyg., 47(3): 66-68 